\title{
Virgin mother or bastard child?
}

\author{
John Dominic Crossan ${ }^{1}$ \\ Emeritus Professor, DePaul University (Chigaco, USA) \\ Visiting Professor: University of Pretoria
}

\begin{abstract}
Virginal conception presumes divine intervention, but divine intervention does not necessarily presume virginal conception. In the case of Mary, two phenomena, both unusual in Jewish tradition, are found, namely divine and virginal conception. This article argues that the virginity claim by Christian Jews preceded and generated the adultery accusation by non-Christian Jews. It does so by stating three points. Firstly, that the earliest dated text containing the accusation of Jesus' bastardy is dependent on the redactional text of Matthew. Secondly, that the general structure of Matthew 1-2 and especially its dyad of Divorce and Remarriage is dependent on the popular traditions about Moses' conception and birth. Thirdly, that the pre-Matthean tradition of divine and virginal conception is rather a reaction against Roman tradition than coming from Jewish tradition. However, this argument does not take Jesus out of Jewish tradition but, places the Judaism of Jesus' time firmly within the Roman Empire. It is a Judaism which opposed Rome's ideological ascendancy and theological eschatology. This article will also be published in A Feminist Companion to (Mariology) or (the Jesus Movement), edited by Amy-Jill Levine, Sheffield: Sheffield Academic Press.
\end{abstract}

\section{INTRODUCTION}

As prologue to my subject, I mention and emphasize that "virginal conception" and "immaculate conception" should be neither confused nor conflated in speaking of Jesus and Mary. Virginal conception refers to the more general Christian belief that Jesus was conceived by divine power, without any human

\footnotetext{
${ }^{1}$ Prof Dr John Dominic Crossan visited the University of Pretoria as guest professor of the Department of New Testament Studies in April 2002. This article is the product of collaboration between Prof Crossan and Prof Dr Andries van Aarde from the Faculty of Theology at the University of Pretoria.
} 
intercourse or intermediary. Immaculate conception refers to the more specific Roman Catholic belief that only those two individuals were conceived without the stain (macula in Latin) of original sin which is, apart from those two exceptions, the common lot of all others descended from Eve and Adam. In that double belief, then, Jesus was conceived both immaculately and virginally, Mary was conceived immaculately but not virginally. The fact that virginal and immaculate conceptions are all too often equated and the later used when the former is intended, has one very serious consequence. Immaculate ("sine macula" in Latin) means unstained or untainted but by original sin and not by human intercourse. When they are equated so that "immaculate" is said when "virginal" is meant, the inference is that the macula/stain of human sexuality has been avoided which presumes, of course, that human sexual relations are normally a stained or tainted proceeding. In itself, however, and apart from individual projections, virginal conception has no such presumption. It simply asserts, forcibly and fully, the power of divine intervention in a child's conception to a virginal mother. Virginal reception could be no more or less than a way of emphasizing that divine intervention.

\section{THE RECIPROCITY OF ANCIENT INVECTIVE}

In any polemical discussion, one can try to debate ideas and/or seek to destroy persons. That latter operation involves, for example, attacking origins, denigrating reputations, impugning motivations, or negating competencies, and it can be done by calling names and/or creating anecdotes, by invidious name-calling or insidious story-mongering. And, in both ancient and modern polemics, those devices work best when they have some basis in reality. Vituperation or invective are normal terms for those polemical maneuvers.

I am indebted here to the expertise of Luke Timothy Johnson but I refer to his study of ancient invective (vituperatio) (Johnson 1989:419-441) rather than to his practice of its contemporary equivalent (Johnson 1996). His detailed documentation shows clearly how character-assassination was normal between competing individuals and groups in the ancient world. Rhetoricians did it to philosophers and philosophers to rhetoricians; Alexandrians did it to Jews and 
Philo did it to Alexandrians; Apion did it to Jews and Josephus did it to Apion and to all other Jews he disliked. It is, in other words, always a case of vice versa. If, then, Johnson's title speaks of "the New Testament's anti-Jewish slander" there must also have been, according to his general argument, some Jewish anti-New Testament slander. But, of course, the mutuality and reciprocity of non-Christian vs Christian Judaism or, later, of Christianity vs Judaism became much worse that name-calling and story-mongering after Constantine. Still, it may be no more historically factual that Mary was an adulteress and Jesus a bastard than that the Pharisees were blind hypocrites and the Jews satanic descendants.

In Johnson's (1989) article the emphasis was on Christian slander against Jewish individuals or groups. That is utterly appropriate not only in terms of the written volume of such slander still extant in Christian texts, minds, and theologies but also from the fact that, eventually, it was Christianity and not Judaism which took hold of Constantine's sword. Thereafter, libel and slander could move from word to deed and from slander to slaughter. But still, and especially when Christian Jewish groups were by far the weaker part of that juxtaposition, the reciprocity or mutuality of invective must be emphasized. In other words, name-calling and story-mongering moved on a two-way street. And, in this article, I reverse Johnson's "anti-Jewish slander" by Christians to speak of "anti-Christian slander" by Jews or, better and more accurately, I will be specifically concerned in this present article with slander against Christian Jews by non-Christian Jews, that is, with those who countered claims of Mary's virginity with the obvious rebuttal of Jesus' bastardy. ${ }^{2}$

\footnotetext{
2 I argued in The birth of Christianity (Crossan 1998:337-342), that a failure to discern the reciprocity of ancient invective marred E P Sanders' reconstruction of Jesus in both Jesus and Judaism (Sanders 1985) and The historical figure of Jesus (Sanders 1993). He is absolutely correct that the idea of Jesus consorting with repentant sinners because his contemporary Judaism would not accept them in the name of God is profoundly wrong about Judaism (on taxcollectors and sinners, see Sanders 1985:177-178; 1993:227, 236, 239; on repentance, see Sanders 1985:202-203, 272-73). But his own idea of Jesus consorting with unrepentant sinners because he himself would accept them in the name of God is just as profoundly wrong about Jesus (see Sanders 1985:108-117, 174-211, 271, 293, 322-323; 1993:230, 235-36). It was not job-description but character-assassination to call the Pharisees hypocrites and whitened sepulchers. It was not job-description but character-assassination to call Jesus glutton and drunkard or his companions tax-collectors and sinners. I cite Sanders in order to emphasize that we must avoid libel or slander in both directions, not only from Christian Jews against nonChristian Jews (of which we have so much extant) but also from non-Christian Jews against Christian Jews (of which we have so little extant). It is under the latter rubric that I discuss the present topic of Mary's virginity or Jesus' bastardy.
} 


\section{FROM JESUS' BASTARDY TO MARY'S VIRGINITY?}

Two books hover around my present discussion and are always there even if not always mentioned. The first, by Jane Schaberg ([1987] 1990), is a detailed exegetical analysis of the infancy stories in Matthew 1-2 and Luke 1-2 as well as historical commentary on their pre-gospel roots and post-gospel effects. Schaberg argues for "Jesus' illegitimate conception, a tradition that is most likely historical. It was minimally theologized in the earliest period, regarded as a begetting through the Holy Spirit. Subsequently, in the gospels of Matthew and Luke, the focus of the tradition was altered by their two distinctive theological and Christological interpretations" so that "the doctrine of the virginal conception is a distortion and a mask" for the fact of that illegitimacy (Schaberg 1990:195, 197). In other words, and in my summary, the fact of Jesus' historical bastardy preceded and generated the claim of Mary's theological virginity.

The second book, by Bruce Chilton (2000), is an interpretive and psychological dramatization of Jesus' life as told in the gospels. The first chapter calls Jesus "A Mamzer from Nazareth." The Hebrew of Dt 23:3a says that no מבמזזר (mamzer) shall be admitted to the assembly of the Lord," the Greek (LXX) translates that mamzer as '́k mopví (from a prostitute)" and the English (NRSV) translates it as "those born of an illicit union" (it is Dt 23:2a in NRSV). On the one hand, nobody knows for certain what that mamzer originally meant. On the other, whether it originally meant and/or was later interpreted as a child of illegitimate parentage, that illegitimacy was much more than mere bastardy. "Jesus was not illegitimate in the modern sense of the word ( $\mathrm{i}$ e, a child born out of wedlock). The term mamzer refers specifically to a child born of prohibited sexual union, such as incest (see Mishnah Yebamot 4:13). The fundamental issue was not sex before marriage (which was broadly tolerated) but sex with the wrong person" (Chilton 2000:13-15) ${ }^{3}$ The English bastard emphasizes a child born outside proper intercourse, a child of parents who were not yet or ever afterwards married. The Hebrew mamzer emphasizes a child born inside improper

\footnotetext{
3 The Mishnah at Yebamoth 4:13 asks "Who is accounted a mamzer?" and an adulterous child from Jerusalem is mentioned among the rabbinical responses, because it was: "[a transgression of the law of] your neighbor's wife" (Danby, The Mishnah, p 225).
} 
intercourse, a child born of parents who could never under any circumstances be married. The mamzer is a child born within forbidden degrees of sexual relationship, be they incestuous, adulterous, or otherwise legally prohibited. The question is not so much whether its parents were legally married or not but whether they could be legally married or not. That is why the decree continues in Deut 23:3b/2b that, "even to the tenth generation, none of their descendants shall be admitted to the assembly of the Lord." Since, for Chilton (2000:20), Jesus was mamzer and not just bastard, "from the beginning of his life Jesus negotiated the treacherous terrain between belonging to the people of God and ostracism in his own community. ${ }^{4}$ For Chilton, furthermore, much of Jesus' life was derived from and explained by that marginalized status. Once again, be Jesus bastard with Schaberg or mamzer with Chilton, the fact of his adulterous conception preceded and generated the claim of Mary's virginal conception. ${ }^{5}$

\section{FROM MARY'S VIRGINITY TO JESUS' BASTARDY?}

My attempt in this article is to reverse that direction of influence and argue that the virginity claim preceded and generated the adultery accusation. The argument will have three points. First, that the earliest dated text containing the

${ }^{4}$ Chilton's argument is that Mary (in Galilean Nazareth) and Joseph (in Galilean Bethlehem) lived in separate villages, therefore they did not have intercourse between betrothal and marriage, and therefore adultery would have been publicly presumed. He cites the Mishnah at Ketuboth 1:8-9 on whether or not the woman's explanation should be believed in such a situation and concludes that, "unless she could bring witnesses to show that she had been in the company of a licit father, it was assumed she had been made pregnant by a mamzer or another prohibited person, so her child was a mamzer" (Chilton 2000:13; but, actually, the responses there are an unresolved debate of positive vs negative). Apart from problems about what was actual law and practice in early first-century Galilean villages, and apart from common sense in a rather delicate area of claim and counter-claim, there is also this other text, not cited by Chilton, from the Mishnah at Kiddushin 4:8, "If a man says, 'This son is a bastard', he may not be believed. Even if they both said of the unborn child in her womb, 'It is a bastard', they may not be believed. R Judah says: They may be believed" (Danby, p 328; once again, an unresolved two-sided debate). Finally, it might be useful to cite the Mishnah at. Horayoth 3:8 as well: "if a mamzer is learned in the Law and a High Priest is ignorant of the Law, the mamzer that is learned in the Law precedes the High Priest that is ignorant of the Law" (Danby, p 466).

${ }^{5}$ See R Joseph Hoffman (1987), Celsus: On the True Doctrine. Celsus is, factually or fictionally, using a Jewish source. See the much fuller discuss of such polemical traditions in Schaberg (1990:165-178). She concludes: 'It appears, therefore, that the tradition of Jesus' illegitimacy in Jewish literature did not simply originate as a reaction to (and distortion of) a Christian claim that Jesus was conceived without a human father" (Schaberg 1990:178). It is my present thesis that it did originate precisely in that way. 
accusation of Jesus' bastardy is dependent on the redactional text of Matthew. Second, that the general structure of Matthew 1-2 and especially its dyad of Divorce and Remarriage is dependent on the popular traditions about Moses' conception and birth. Third, that the pre-Matthean tradition of divine and virginal conception is more against Roman tradition than from Jewish tradition.

\subsection{Celsus and Matthew}

Actually, however, the first person to imagine adulterous conception was not a non-Christian opponent and the first person to record that accusation was not an anti-Christian polemicist. The first to imagine it was Joseph and the first to record it was Matthew 1:18-19: "Now the birth of Jesus the Messiah took place in this way. When his mother Mary had been engaged to Joseph, but before they lived together, she was found to be with child from the Holy Spirit. Her husband Joseph, being a righteous man and unwilling to expose her to public disgrace, planned to dismiss her quietly."

Why on earth did Matthew record it that way? Even within the constraints of an infancy narrative and a virginal conception, Joseph's thoughts and/or Matthew's comments about Mary's adultery were not at all inevitable.

First, in contrast, notice how Luke just lets the reader presume that, after the annunciation, Mary informed Joseph of their destiny, and all went well. That is what explicitly happened between Eluma and Manoah when the angel informed her that her sterility would end and she would bear a son named Samson. "She came into the house to her husband and said to him ... the angel of the Lord came to me and revealed to me, saying, 'Eluma you are sterile but you will conceive and bear a son"' (Pseudo-Philo, Liber Antiquitatum Biblicarum 42:4; see Judges 13:3-6).

Second, even if Matthew wanted to tell the story from Joseph's perspective, unlike from Mary's perspective as in Luke, he could easily have had that angel interrupt Joseph's dreams a month or so earlier and inform him of Mary's divinely virginal pregnancy before he found out by himself that something unusual had happened.

Third, if Matthew wanted to maintain male ascendancy, he could thereafter have Joseph inform Mary of her destiny, as Amram did Jochebed in Josephus' 
version of Moses'conception: "These things revealed to him in a vision, Amram on awaking disclosed to Jochabel(e), his wife" (Jewish Antiquities 2.217). Why ever bring up the thought of adultery and the possibility of divorce? Even Matthew himself seems quite aware of and defensive about the dangers of his narrative. That, at least, is one very plausible explanation of those four women in Jesus' genealogy who stand out so emphatically among men generating men. ${ }^{6}$

My answer will be that Matthew was creating Jesus' infancy story on the model of Moses' birth narrative but not just as told in Exodus 1-2, rather as already filled out extensively in popular tradition by midrashim and/or targumim before and after his own first-century context. That thesis will be the argument of the next section.

\subsection{Moses and Midrash}

In the ancient world, an infancy-story was often a life's overture and, where little was known about a protagonist's conception and birth, they could be invented on that principle. In Matthew 5-7 Jesus would appear as a new Moses giving a new Torah from a new Mount Sinai. What, then, could be more appropriate than to create an infancy story for Jesus modeled on that of Moses? And, also in that ancient world, where the old was good and the new suspect, new meant the old renewed and not replaced.

First, when one reads the biblical story of Moses' conception and birth in Exodus 1-2 certain questions come to mind. Why is it that Moses just happened to be born at a time of general pogrom against the children of Israel (in three steps: see Exodus 1:13, 15, 22)? Is that not too accidental or too nonprovidential? Why did his parents-to-be, and all other such Israelite parents, not do something to defeat the decree of Pharaoh? Why not cease intercourse, choose separation, or attempt divorce? Popular expansions in targumim or midrashim answered those questions by inventing details to answer both those

\footnotetext{
6 Tamar, Rahab, Ruth, and Bathsheba are mentioned in Matthew 1:3-6. "It is the combination of the scandalous or irregular union and of divine intervention through the woman that explains best Matthew's choice in the genealogy" but "we should not rule out a subordinate motif stemming from .... Matthew's interest that the four OT women were also Gentiles or associated with Gentiles," according to Raymond E Brown (1993:74).
} 
problematic questions. The full story then became a three-act drama involving what I term The King's Decree, then The Father's Decision, and finally The Child's Escape. That final act needed little improvement: the basket, the bullrushes, and Pharaoh's daughter were hard to better.

Second, I first worked on those popular versions over forty years ago but then and now I am extremely indebted to the work of Renée Bloch. ${ }^{7}$ She explored the haggadic midrashim about the birth of Moses, focused on the first of those two literary topics which I noted above (The King's Decree), and did not continue into the second one (The Father's Decision). ${ }^{8}$ My own work on both those topics is totally dependent on her original contribution. ${ }^{9}$ Bloch made these four very persuasive suggestions. First, haggadic midrashim are more stable than halakhic ones. ${ }^{10}$ Second, even very late redactions may contain very

7 I used Bloch's ([1954:210-285] 1955a:93-167; [1955b:194-227] 1978:51-75) writings in 1960-61 in a thesis-paper for Francis McCool, S J, at the Pontifical Biblical Institute in Rome and I then had available copies of all her original sources. That allowed me to study not only The King's Decree tradition (which she had already done so fully) but also the accompanying tradition of The Father's Decision (which she had not considered but for which she had, of course, cited all the sources). Next, that paper was given as a lecture at St Joseph's Oratory, Montreal, in May of 1965, and then published as the "Structure and theology of Matthew 1.18-2.23 in Cahiers de Joséphologie 16 (1968), 119-135, Finally, I revised it as "From Moses to Jesus: Parallel themes," published in Bible Review 2(2) 1986, 18-27. That longevity does not prove me correct, simply persistent. Also, in the early 1960s, I was far more ready than later to speak of Matthew knowing "history, older traditions of what had actually happened at Jesus' birth" (Crossan 1968:133). Some of that was possibly ecclesiastical prudence but mostly it was professional ignorance.

${ }^{8}$ Her inventory included, of course, the earlier texts from Josephus and Pseudo-Philo but also a millennium-span of later texts, the Targum Pseudo-Jonathan [her Targum of Jerusalem], the Dibre ha-Yamin shel Moshe or Chronicle of Moses, the Sefer ha-Yashar, the Yalqut Shim'oni and the Sefer ha-Zikhronot. For Bloch, the tradition is not "the product of scholars and schools"but a popular product ... from the preaching done in the synagogue every Sabbath and festival day, after the reading of the Torah, on the section of Scripture which had just been read" (Bloch 1978:60). In this article I have deliberately chosen both the first-century texts and the first and last of her five examples.

${ }^{9}$ Rabbinic tradition recognizes two versions of the proclamation of Moses' birth: (1) Pharaoh's dream and the magicians' prediction and (2) Miriam's prophecy. The example we provide here to illustrate the proposed method is based only on the first, Paharoh's dream and the magiciam's prediction" (Bloch 1978:61). For my present purpose of comparing Matthew with those popular traditions, I rephrase her twin titles, Pharaoh's Dream and Miriam's Prophecy, as The King's Decree and The Father's Decision.

10 [T]he aggadah, essentially homiletic in nature, represents an intrinsically religious meditation on immutable sacred texts; it is much less subject to fluctuation, to adaptation to ever-changing circumstances, than is the halakah, whose nature is essentially practical. Thus the aggadah has a much more stable nature, one more apt to conserve extremely ancient traditions" (Bloch 1978:54). 
ancient traditions. ${ }^{11}$ Third, the earliest dated documents which contain those traditions, for example, first century texts such as Josephus or Pseudo-Philo, indicate a relatively firm terminus a quo for their existence. ${ }^{12}$ Fourth, Matthew 1-2 is another first-century text that already knew those Mosaic birth-traditions. ${ }^{13}$

Third, each of those new post-biblical acts had four basic scenes. The Kings' Decree involved Dream, Fear, Message, and Plot. Those three initial scenes gave new background to the final Plot scene which came from Exodus 1:22 (the murder of the infant males). The Father's Decision had Divorce, Prophecy, Remarriage scenes as new background for the final Birth scene which came from Exodus 2:1-2 (the birth of Moses). Those italicized terms will be used as formal elements for the rest of this article.

Fourth, for those two new acts I look at four deliberately chosen texts. The first two are from the first century, from its start and from its end. The second two are from much, much later, from half and then a full millennium later. That juxtaposition is quite deliberate since my proposal is that the structural matrix or topical sequence of those twin acts (but not, of course, the minor details) was there even before the turn of the era. That argument depends primarily on the first and most important of the four texts and I begin with it.

\footnotetext{
${ }^{11}$ It is possible, however, that certain of these documents may be of late redaction and nevertheless contain traditions which date back to a very ancient period. In any case, so long as these questions are not resolved, this entire literature remains misleading and unusable" (Bloch 1978:55).

12 S]ince the present forms of the rabbinic writings through which we know the aggadic traditons are of later redaction, from where could these ancient authors [Josephus and Pseudo-Philo] have drawn the aggadic traditions they used in their work? (For no one would imagine that these traditions might depend on Josephus or Pseudo-Philo.) It is historically impossible to resort to the hypothesis of a purely oral tradition. It remains, therefore, to postulate one or several common, written aggadic sources anterior to both Josephus and Pseudo-Philo" (Bloch 1978:58).

13 Matthew in particular, the most "rabbinic" of the evangelists, in the account concerning the birth of Jesus contained in his Chapter II), obviously presupposed the aggadic tradition of Moses' birth. Jesus, acknowledged as Messiah, was considered a second Moses, and it was natural for the evangelist constantly to refer to the traditions concerning Moses' birth in order to formulate those relating to the birth of Jesus. "From her chosen case-study of The King's Decree, she then cites: "the parallelism of the two figures and their role as saviors; parallelism of the predictions of their birth, attributed in each case to official scribes; parallelism of the two tyrants, Pharaoh and Herod; parallelism of the massacre ordered by each to kill the future savior and thereby to prevent the realization of the prediction" (Bloch 1978:67).
} 


\subsubsection{Pseudo-Philo's Liber Antiquitatum Biblicarum [LAB]}

This text is crucial for my argument but its earliest extant manuscripts are Latin ones that date to the $11^{\text {th }}$ century from Germany or Austria. ${ }^{14}$ But its original language was Hebrew (not Aramaic) and thence it was translated into Greek and thence into Latin. ${ }^{15}$ And, judging from the biblical text used in this expansioncommentary, it came from Palestine. ${ }^{16}$ Finally, it comes, most likely, from "a date around the time of Jesus" and "seems to reflect the milieu of the Palestinian synagogues at the turn of the common era" (Harrington 1985:299, 300). ${ }^{17}$ Whether one thinks of "synagogues," in that time and place, as buildings or, more likely, as gatherings, such popular narratives would be how ordinary people in the Jewish homeland heard and remembered their ancestral traditions. In summary, then, this expansive commentary on certain biblical stories was for popular rather than scholarly consumption, from a Palestinian rather than a Diaspora situation, and with an original date from the start rather than the end of the first commonera century. It represents "one of the most significant links between early haggadah and rabbinic Midrash" (Louis G Feldman, "Prolegomenon," p IX). ${ }^{18}$

${ }^{14}$ There is an older English translation, based on the 1527 Latin editio princeps and some other manuscripts by M[ontague] R[hodes] James ([1917] 1971. One modern critical edition, with no translation, based primarily on the $11^{\text {th }}$ century Ms Admont 359, is by Guido Kisch (1949).

Another one, with French translation, based primarily but not exclusively on the $11^{\text {th }}$ century Ms Fulda-Cassel Theol. $4^{\circ}, 3$ and the $12^{\text {th }}$ century Ms Phillipps 461 , is by Daniel J Harrington, Jacques Cazeaux, Charles Perrot, \& Pierre-Maurice Bogaert (1976). The English translation I use here, based on that latter critical text, is by Daniel J Harrington (1985:297-377).

15 The "Latin form of $L A B$ is not an original composition but rather is a translation from a Greek text which, in its turn, is based upon a Hebrew [not an Aramaic] original" (see Harrington 1970:504).

16 The biblical text used in $L A B$ "is neither Babylonian (=MT) nor Egyptian (=LXX); rather it is Palestinian" (see Harrington 1971:16).

17 Again: "The original date of composition is controverted. A date around the turn of the era is likely for the following reasons: the silence about the destruction of the Temple, the assumption that the Temple cult was still going on, and the use of an Old Testament text that seems to have been suppressed after AD 100" (see Harrington 1989:317). Pierre-Maurice Bogaert (1976.2:74) proposes a date not after but before $70 \mathrm{CE}$ as "most probable." But, while he admits that nothing would "clearly" exclude a date as far back as Pompey in the first century BCE, LAB's stylistic and ideological links with immediately post-70 CE works precludes dating $L A B$ that early without "decisive reason" (see Bogaert (1976.2:74).

18 Feldman's description was repeated in his article on "Josephus' Jewish Antiquities and Pseudo-Philo's Biblical Antiquities" (see Feldman 1989:59). Charles Perrot (1976.2:31) locates $L A B$ within "popular Judaism in the widest sense" rather than in any sectarian, apocalyptic, gnostic or esoteric environment. It represents Pharisaic instruction on "the ideas and themes most widely disseminated (vulgarisés) in the Judaismn of the first century of our era." 
In this pre-Matthean source Moses' conception in $L A B$ 9:1-10 has nothing about The King's Decree but gives The Father's Decision in extended (if not quite coherent) detail. Amram and Jochebed are not yet married when the decree is promulgated and the question is whether any future marriage, including their own, should take place under the threat of male infanticide:

Then the elders of the people gathered the people together in mourning [and said].... "let us set up rules for ourselves that a man should not approach his wife .... until we know what God may do." And Amram answered and said .... "I will go and take my wife, and I will not consent to the command of the king; and if it is right in your eyes, let us all act in this way. And the strategy that Amram thought out was pleasing before God. And God said .... "He who will be born from him will serve me forever." And Amram of the tribe of Levi went out and took a wife from his own tribe. When he had taken her, others followed him and took their own wives .... And this man had one son and one daughter; their names were Aaron and Miriam. And the spirit of God came upon Miriam one night, and she saw a dream and told it to her parents in the morning, saying: I have seen this night, and behold a man in a linen garment stood and said to me, "Go and say to your parents, 'Behold he who will be born from you will be cast forth into the water; likewise through him the water will be dried up. And I will work signs through him and save my people, and he will exercise leadership always." And when Miriam told of her dream, her parents did not believe her.

Notice some details. First, it is not a question of Divorce and Remarriage but of Abstinence or Intercourse (for all) and Non-Marriage or Marriage (for Amram). Second, when later $L A B$ 42:1 expands on Samson's conception as here on Moses', Manoah says to Eluma: "'Behold the Lord has shut up your womb so that you may not bear children, and now let me go that I may take another wife lest I die without fruit."' The Divorce element has slipped over from Moses' parents to Samson's. Third, Amram's faith causes God's decision that Moses will be his child but God's Prophecy is not communicated to anyone at the time. Fourth, Amram's marriage to the unnamed Jochebed, the births of Aaron and Miriam, and the latter's growth past childhood ensues, with a consequent multi-year timelapse between The King's Decree (in its biblical not popular version) and The 
Child's Birth. Fifth, Miriam's dream-revelation and parental Prophecy has no causative effect on the marriage situation and, besides, is not believed. ${ }^{19}$ Finally, in somewhat compensation for Miriam's tangential importance, Amram's Godpleasing strategy is explicitly based on what "our mother Tamar did" (9:5; see Gen 38). That may well be redactional rather than traditional so it could hardly influence Matthew's mention of Tamar in 1:3. But, at least, both Pseudo-Philo and Matthew were quite ready to acknowledge Tamar as a positive ancestress. All in all, however, this is not exactly the smoothest version of The Father's Decision.

\subsubsection{Josephus, Jewish Antiquities [JA].}

The second text is an account of biblical antiquities dated to the end of the first common-era century, around 93-94 in Rome. It contains both acts, The King's Decree and The Father's Decision, but the latter is much shorter than in PseudoPhilo.

The King's Decree. It was not that Moses just happened to be born after Pharaoh's decree of genocide was promulgated. One of his advisers warned of danger for Egypt from a soon-to-be-born Jewish child who would both threaten them and save his fellow Israelites, according to JA 2.205-206 (see Thackeray et al 1926-65):

While they were in this plight, a further incident had the effect of stimulating the Egyptians yet more to exterminate our race. One of the sacred scribes--persons with considerable skill in accurately predicting the future--announced to the king that there would be born to the Israelites at that time one who would abase the sovereignty of the Egyptians and exalt the Israelites, were he reared to manhood, and would surpass all men in virtue and win everlasting renown. Alarmed

19 Since, "on the whole, Pseudo-Philo portrays women more positively than does Josephus," as shown by Cheryl Anne Brown (1992:212), it is possible that Pseudo-Philo introduces Miriam into the story at this point (rather than Josephus omitting her). But, first, her role is not exactly important and, second, her intervention is causally important in all later versions of the tradition save for the Targum of Jerusalem. More likely, then, it came quite inaugurally from Miriam's prophetic stature in Exodus 15:20-21 and was part of the story's basic matrix. $L A B$ may have down-played her importance to focus exclusively on the faith and righteousness of Amram. 
thereat, the king, on this sage's advice, ordered that every male child born to the Israelites should be destroyed by being cast into the river.

In this version there is no Dream and the Message is, therefore, not an interpretation of Pharaoh's dream. But Moses-to-be was the occasion and not just the accident of that general slaughter. You can see immediately how much better the popular version is than the biblical one for Matthew's purpose. Herod the Great is the new Pharaoh the Oppressor. Both receive learned advice about the soon-tobe-born child. Herod gets it from "all the chief priests and scribes of the people" in Matthew just as Pharaoh got it from "one of the sacred scribes" in Josephus. Both determine on a general male infanticide to destroy the destined child, be it Moses or Jesus.

The Father's Decision. In JA 2.210-211 Amram and Jochebed are already married and pregnant when Pharaoh's decree is promulgated so there is no question of any multi-year time lapse:

\begin{abstract}
Amaram(es), a Hebrew of noble birth, fearing that the whole race would be extinguished through lack of the succeeding generation, and seriously anxious on his own account because his wife was with child, was in grievous perplexity. He accordingly had recourse to prayer to God .... And God had compassion on him and, moved by his supplication, appeared to him in his sleep, exhorted him not to despair of the future, and told him that ... "This child, whose birth has filled the Egyptians with such dread that they have condemned to destruction all the offspring of the Israelites, shall indeed be yours; he shall escape those who are watching to destroy him, and, reared in a marvelous way, he shall deliver the Hebrew race from their bondage in Egypt, and be remembered, so long as the universe shall endure, not by Hebrews alone but even by alien nations."
\end{abstract}

Again, notice some details. First, there is nothing about any transition of Abstinence/Intercourse, Non-Marriage/Marriage, or Divorce/Remarriage. Second, other parents are not involved, there is only Amram and his pregnant wife. Third, perplexity and prayer lead to a dream-revelation and a divine Prophecy but this time directly from God to Amram. Miriam is not even present. Finally, notice that, in both acts, Josephus extends Moses' destiny beyond being anti-Egypt and pro- 
Israel so that, in the first act, he "would surpass all men in virtue and win everlasting renown," and, in the second one, he will "be remembered, so long as the universe shall endure, not by Hebrews alone but even by alien nations."

\subsubsection{Targum Pseudo-Jonathan [TPJ] or Targum of Jerusalem I}

The third text is dated, in its present state, to the second half of the seventh century. ${ }^{20}$ That is obviously much later than Matthew and I use it here as a late post-Matthean text for deliberate comparison. It contains both acts, as in Josephus, and not just the second one, as in Pseudo-Philo.

The King's Decree. This act is more developed than the previous version in Josephus. The story does not start with a Message from the advisors but with a Dream of Pharaoh to which the advisors furnish their Message as interpretation:

And Pharaoh said (that while) he slept, he saw in his dream that all the land of Egypt was placed on one balance of a weighing-scales, and a lamb, the young (of a ewe), on the other balance of the weightingscales; and the balance of the weighing-scales on which the lamb (was placed) weighed down. Immediately he sent and summoned all the magicians of Egypt and told them his dream. Immediately Jannes and Jambres, the chief magicians, opened their mouths and said to Pharaoh: "A son is to be born in the assembly of Israel, through whom all the land of Egypt is destined to be destroyed."

The advisors are named as Jannes and Jambres. And, while Dream is now present, Fear is absent.

The Father's Decision. This act, on the other hand, is much less developed than the version in Pseudo-Philo and even less than the one in Josephus:

Amram, a man of the tribe of Levi, went and seated under the bridal canopy and (in) the wedding chamber Jochebed, his wife, whom he had divorced because of Pharaoh's decree. Now, she was a hundred and thirty years old when he took her back. But a miracle was

20 The translation I use is that of Michael Maher (1994:162-164). 
performed for her, and her youth was restored just as she was when she was young (and) called a daughter of Levi. The woman conceived and bore a son at the end of six months.

That version does not mention other parents-to-be, does have Amram and Jochebed divorced and then remarried, has no specific motivation for the transition, and contains no dreams, revelations, or prophecies whatsoever. But it does have one special miracle for Jochebed.

\subsubsection{Sefer ha-Zikhronot [ShaZ] or Book of Memoirs.}

The final text is dated more than a millennium after Matthew, to the start of the fourteenth century. On the one hand, that makes it easily dismissed as irrelevant. But, on the other, how does one explain the structural similarities and topical resemblances between those two first-century texts ( $L A B \& J A)$ and these much, much later ones (TPJ \& ShaZ)? ${ }^{21}$

${ }^{21}$ For example, Raymond E Brown (1993:600), comments that, "In a popular article Crossan [1986] concentrates on the Mosaic-birth background. The treatment is problematic in several ways, however, for he neglects the OT Joseph and Balaam contribution, and into the midrashic developments centered on the birth of Moses he brings the $12^{\text {th }}$-century-AD Sepher ha-Zikronot, assuming that minor narrative details there 'record a structure already present in the first century' ([Crossan 1986:]21). This type of assumption, in my judgment, is dangerous, often leading to an unscientific, anachronistic application of Jewish materials to the NT. Crossan is correct, however, in adding to the midrashic background pseudo-Philo's Biblical Antiquities, which I largely neglected" in the first edition of The Birth of the Messiah. If all we had were Matthew 1-2 and the Sefer ha-Zikhronot, folios 37-38, that would be a telling criticism but we have: (1) a start-of-thefirst-century version in Pseudo-Philo and an end-of-the-first-century version in Josephus, with (2) the earlier Pseudo-Philo having only the Father's Decision, the later Josephus having both The King's Decree and The Father's Decision, but the earlier Pseudo-Philo being much more developed for The Father's Decision than the later Josephus, and (3) and the several versions of the continuing tradition across the next millennium, so that (4) we must almost necessarily postulate a rather full general structure even before the start of the first century. It is possible but hardly likely that the Sefer ha-Zikhronot has adapted its narrative to that of Matthew 1-2, so I propose that the structural matrix and topical sequence seen in its story was present already before either Pseudo-Philo, Matthew, or Josephus. Finally, and most importantly, once PseudoPhilo becomes properly basic to the discussion, two results ensue. One is that the first extant manuscripts for Pseudo-Philo date to the $11^{\text {th }}$ century and, there, we do not confuse date of tradition with date of manuscript. Another is that the later redactor who added the Mosaic infancy tradition in ShaZ 1 retrojected $L A B$ 9:1-10 and several other sections back into Hebrew. He did so from some now unidentifiable Latin manuscript(s) which might have been as good as any we now have. Imagine, then, that we had lost all those Latin manuscripts, what would we have judged about that Hebrew text [ShaZ 1] from the fourteenth century? Would we ever have presumed it had descended relatively securely from a first-century tradition? (Postscript: I think there is a misprint in Brown 1993:114 on this Mosaic conception tradition in "the Life of Moses by Philo." That should be Pseudo-Philo, as is contextually clear, but the misprint reminds us that Philo himself does not have this tradition in his De Vita Mosis I. It was presumably strictly Palestinian. 
The Sefer ha-Zikhronot is a compendium of midrashim dated to $1325^{22}$ and contains two versions of those popular Mosaic infancy expansions [ShaZ $1 / 2]^{23}$ Since the later but now first-in-place one [ShaZ 1 ] is simply a retroversion into Hebrew of the Latin story in Pseudo-Philo (see Harrington 1974), ${ }^{24}$ I do not use it here but work only with the earlier but now second-in-place one [ShaZ 2]. ${ }^{25}$ That means, of course, that ShaZ 1 has only one act of the expanded drama, The Father's Decision, while Shaz 2 has both acts. ${ }^{26}$

The King's Decree. This version has all four scenes: Dream, Fear, Message, and Plot. The first three preface the fourth one from the biblical story at Exodus 1:15:

22 The only extant copy is in Oxford University's Bodleian Library as Oxford Ms Heb d 11 (Catalogue No. 2797). I have not seen the original vellum manuscript and only have photostats of the pertinent texts on folios 37-38. There is an English translation by Moses Gaster in Eleazar ben Asher ha-Levi, The Chronicles of Jerahmeel or, The Hebrew Bible Historiale. Being a Collection of Apocryphal and Pseudo-Epigraphical Books Dealing with the History of the World from the Creation to the Death of Judas Maccabeus. Translated for the first Time from an Unique Manuscript in the Bodleian Library. Oriental Translation Fund, ns 4. London: Oriental Translation Fund Publications, 1899. Reprint, with "Prolegomenon" by Haim Schwarzbaum. New York, NY: Ktav, 1971. Some details: Jerahmeel ben Solomon was from the $12^{\text {th }}$ century; ben Asher compiled his collection in the Rhine Provinces, $1325 \mathrm{CE}$; the manuscript was bought by the Bodleian in 1887; in the 1971 edition (which I used) the "Preface" by Moses Gaster [1856-1939] is on pp vii-cxii, and the "Prolegomenon" by Haim Schwarzbaum is on pp 1-124. But, most importantly, Gaster only translated the first part of the manuscript, that is, folios 7b-103b of 338 folios]. The English title for Sefer ha-Zikhronot is the Book of Memoirs or Remembrances or Records, recalling Esther 6:1.

${ }^{23}$ In general, "two hands are clearly visible in the manuscript. The older one (in a very different script, on a much older parchment, annotated in the margins by the redactor) covers [certain folios, including folio 38]. The other, the 'redactor's' hand covers all the rest of the manuscript [including folio 37] with his German rabbinic script; the handwriting is certainly much more recent" (Bloch 1978:73, note 38). Save for parchment age, those divergences are clearly evident even on photostats as are the different number of lines per folio (around 30 for folio $38 r$ \& $v$ but 40 for folio $37 r$ \& v). I distinguish those twin versions here as ShaZ 1/2 where ShaZ 1 is the first given but more recent version on folio 37 and ShaZ 2 is the second given but older one on folio 38 .

${ }^{24}$ In his The Hebrew Fragments of Pseudo-Philo's Liber Antiquitatum Biblicarum Preserved in the Chronicles of Jerahmeel, Daniel J Harrington (1974:7) concludes that the Chronicles of Jerahmeel (CJ) "could have used an early MS. And so $C J$ could possibly witness to a stage in transmission prior to the division [of $L A B$ 's Latin manuscripts] into two major groups. On the other hand, the author could have used more than one manuscript."

25 Those versions are, respectively, in the vellum original: folios 37 and 38; in the 1971 reprint (see note 22 above): Chapters XLII.5-8 (pp 104-106), untitled, and Chapters XLIII.1-2 \& XLIV.1-2 (pp 106-109), titled "The Chronicles of Moses." On those sections see the "Prolegomenon" (pp 54-55) and the "Preface" (pp Ixxxvii-xci).

${ }^{26}$ My translation is that of Moses Gaster (in Eleazar ben Asher ha-Levi [1899] 1971:106-109). 
[Dream] In the $130^{\text {th }}$ year after the Israelites had gone down to Egypt, Pharaoh dreamt a dream. While he was sitting on the throne of his kingdom he lifted up his eyes, and beheld an old man standing before him. In his hand he held a pair of scales as used by merchants. The old man then took the scales and, holding them up before Pharaoh, he laid hold of all the elders of Egypt and its princes, together with all its great men, and, having bound them together, placed them in one pan of the scales. After that he took a milch goat, and, placing it on the other pan, it outweighed all the others. Pharaoh then awoke, and it was a dream.

[Fear] Rising early next morning, he called all his servants, and told them the dream. They were sorely frightened by it,

[Message] and one of the king's eunuchs said, "This is nothing else than the foreboding of a great evil about to fall upon Egypt." On hearing this the king said to the eunuch, "What will it be?" And the eunuch replied, "A child will be born in Israel, who will destroy all the land of Egypt. If it is pleasing to the king, let the royal command go forth in all the land of Egypt that every male born among the Hebrews should be slain, so that this evil be averted from the land of Egypt."

[Plot] The king did so and accordingly sent for the Hebrew midwives ....

In that story, the Fear element is not just for Pharaoh, as in Josephus, but for all his servants. Also, the Message concerns a child who will be anti-Egypt with nothing about pro-Israel. That is more like the Targum Pseudo-Jonathan than Josephus.

The Father's Decision. I leave aside other traditions about how God saved the new-born Israelite children and concentrate on the four scenes of Divorce, Prophecy, Remarriage, and Birth.

- $\quad$ [Divorce] When the Israelites heard this command of Pharaoh to cast their males into the river, some of the people separated from their wives, while others remained with them

- $\quad$ [[there follow two separate traditions about male children hidden by God beneath the earth or protected by beasts in the forest]] ... 
- $\quad$ [Divorce] When, however, the word of the king and his decree became known respecting the casting of their males into the river, many of God's people separated from their wives, as did Amram from his wife.

- $\quad$ [Prophecy] After the lapse of three years the Spirit of God came upon Miriam, so that she went forth and prophesied in the house, saying, "Behold, a son shall be born to my mother and father, and he shall rescue the Israelites from the hands of the Egyptians."

- $\quad$ [Remarriage] When Amram heard his young daughter's prophecy he took back his wife, from whom he had separated in consequence of Pharaoh's decree to destroy all the male line of the house of Jacob. After three years of separation he went to her and she conceived.

- $\quad[$ Birth $]$ And it came to pass at the end of six months from the time of her conception that she bore a son. The whole house was at that moment filled with a great light, as the light of the sun and the moon in their splendour. The woman saw that the child was good and beautiful to behold, so she hid him in an inner room for three months.

In this version, the Prophecy element is not God to self and angel to Miriam, as in Pseudo-Philo, or God to Amram directly, as in Josephus. But, more significantly, the Prophecy of Miriam directly causes the transition from Marriage to Remarriage and it is a spirit-driven prophecy rather than a dream-given revelation. Also, her Prophecy contains the pro-Israel parallel to the anti-Egypt Message earlier.

\subsubsection{Structural matrix and textual redactions}

What is most striking in those four texts is their structural similarity across more than a millennium of Jewish tradition. Here is a summary table of the major elements in those extra-biblical expansions: 


\begin{tabular}{|c|c|c|c|c|c|}
\hline Elements & Texts & $\begin{array}{l}\text { Pseudo- } \\
\text { Philo, } \\
L A B \\
\text { 9:2-10 }\end{array}$ & $\begin{array}{l}\text { Josephus, } \\
\text { JA } \\
2.205-206\end{array}$ & $\begin{array}{l}\text { Targum } \\
\text { Pseudo- } \\
\text { Jonathan }\end{array}$ & $\begin{array}{l}\text { Sefer ha- } \\
\text { Zikhronot } 2 \\
\text { folio } 38\end{array}$ \\
\hline \multirow{4}{*}{$\begin{array}{l}\text { The } \\
\text { King's } \\
\text { Decree }\end{array}$} & Dream & ----- & ----- & $\begin{array}{l}\text { lamb out- } \\
\text { balances } \\
\text { Egypt }\end{array}$ & $\begin{array}{l}\text { kid out- } \\
\text { balances } \\
\text { Egypt }\end{array}$ \\
\hline & Fear & ----- & Pharaoh & ----- & servants \\
\hline & Message & & $\begin{array}{l}\text { anti-Egypt } \\
\& \\
\text { pro-Israel }\end{array}$ & anti-Egypt & anti-Egypt \\
\hline & Plot & Exodus 1 & Exodus 1 & Exodus 1 & Exodus 1 \\
\hline \multirow{4}{*}{$\begin{array}{l}\text { The } \\
\text { Father's } \\
\text { Decision }\end{array}$} & Divorce & $\begin{array}{l}\text { all decide } \\
\text { against } \\
\text { marital } \\
\text { intercourse }\end{array}$ & $\begin{array}{l}\text { only Amram, } \\
\text { is perplexed, } \\
\text { and prays }\end{array}$ & $\begin{array}{l}\text { only Amram, } \\
\text { divorces wife }\end{array}$ & $\begin{array}{l}\text { some, like } \\
\text { Amram, } \\
\text { divorce } \\
\text { wives }\end{array}$ \\
\hline & Prophecy & $\begin{array}{l}\text { God to self \& } \\
\text { angel to Miri- } \\
\text { am (dream) }\end{array}$ & $\begin{array}{l}\text { God to } \\
\text { Amram } \\
\text { (dream) }\end{array}$ & ------ & $\begin{array}{l}\text { Miriam to } \\
\text { Amram } \\
\text { (no dream) }\end{array}$ \\
\hline & Remarriage & $\begin{array}{l}\text { Amram } \\
\text { refuses } \\
\text { general } \\
\text { decision }\end{array}$ & $\begin{array}{l}\text { Amram tells } \\
\text { pregnant } \\
\text { Jochebed }\end{array}$ & $\begin{array}{l}\text { only Amram, } \\
\text { remarries } \\
\text { wife }\end{array}$ & $\begin{array}{l}\text { only Amram, } \\
\text { remarries } \\
\text { wife }\end{array}$ \\
\hline & Birth & Exodus 2 & Exodus 2 & Exodus 2 & Exodus 2 \\
\hline
\end{tabular}

First, some fifty years ago, when Renée Bloch studied those texts and several other midrashim, she intended to see if the developmental evolution of their 
traditions could be correlated with the chronological sequence of the texts which contained them. For that purpose, her specific case-study was The King's Decree within the extra-biblical and popular narratives about Moses' conception and birth. ${ }^{27}$ I do not think such correlation is possible because, even when there is a genetic sequence between two texts, the dependent one can always shorten as well as lengthen, improve as well as disimprove, the earlier one. Just recall what Matthew and Luke can do to a text they are copying from Mark.

Second, looking across the above table, you notice that: (1) $L A B$ has more than JA for The Father's Decision; (2) JA has The King's Decree which $L A B$ lacks; (3) JA has less than TPJ for The King's Decree but more than TPJ for The Father's Decision.

Third, the Divorce/Remarriage elements are quite varied. They are invested as Abstention/Intercourse as well as Non-Marriage/Marriage or even completely omitted. They involve Amram and Jochebed alone, or along with some parents, or along with all parents-to-be. And Amram refuses or accepts a general decision.

Fourth, the Prophecy element is also quite diverse and has one very interesting difference. It may be from God to self, God to Amram, or Miriam to Amram and Jochebed. In ShaZ 2, for example, her prophecy is the causal link that moves Divorce to Remarriage. There is, however, one other way of registering Miriam's causal influence. She rebukes Amram because Pharaoh's decree would have attacked only male infants but his divorce attacked females as well. "When Amram separated from his wife on account of the edict published against the male children of the Hebrews, his daughter Miriam said to him:

27 "This work essentially traces a single tradition through the various stages represented by the different documents. It tries to distinguish the most primitive elements and the variants, the developments, the additions and the revisions; it takes account of the diversity of literary genres and historical situations. It does all this in order provisionally to classify the writings according to the evolution of the observed tradition" (Bloch 1978:60). And again: "It is understood that, before advocating a precise chronological order, an analagous exercise of literary criticism must be carried out for a certain number of important traditions contained in these books. In the present article we simply suggest a method and illustrate it with an example" (Bloch 1978:64-65). 
'Father, your decree is worse than Pharaoh's decree. The Egyptians aim to destroy only the male children, but you include the girls as well."'28

Fifth, the basic topical structure is quite similar despite some significant differences. Pharaoh has a Dream in which a young animal outweighs Egypt on the scales of a balance. He and/or his advisors show Fear when told of it and give as its Meaning the birth of a Hebrew child who will save his people but damage Egypt. Hence Pharaoh's Plan of extermination which is now specifically to kill the savior-child. Hearing of it, some Hebrew parents choose Divorce but Miriam's dream and Prophecy persuade them to Remarriage so that the Birth of Moses can follow. I think that basic two-act and eight-scene dramatic structure was there before $L A B$ used only its second act, JA abbreviated both acts, and TPJ expanded the first act but abbreviated the second one. I find that more plausible than to imagine a slow and linear growth starting with, say, Josephus. Of course details are added or omitted, changed or developed, but the structure is relatively stable and shorter vs longer cannot be equated with earlier vs later.

\section{MIDRASH AND MATTHEW}

My argument is that the general structure of twin acts and eight scenes from the popular traditions of Moses' conception and birth gave Matthew the basic structure for his story about Jesus' conception and birth. ${ }^{29}$ That explains, by the

28 That quotation is from the integrated harmony of Mosaic infancy traditions in Louis Ginzberg (1956:287), Legends of the Bible; the shorter version of his 7-volume The Legends of the Jews. He gave the sequence as: (1) Amram, with all others following him, divorce their wives; (2) Miriam's reproof causes their remarriage; (3) Amram is uneasy so God reassures him in a dream; (4) Miriam also has a prophetic dream and tells her parents. That fits everything into one coherent story.

${ }^{29}$ Daniel J Harrington (1989), comments that "I do not envision a relationship of direct dependence between these texts [LAB and either Matthew 12-2 or Luke 1-2]". That is correct but we can surely say more than the following, at least about Matthew 1-2: "The parallels show that roughly contemporaneous writers with differing methods and concerns used some of the same literary devices and motifs in telling the stories about the births of their heroes. This modest conclusion is enough for me" (Harington 1989:324). I prefer less modesty, like this: in midrash, pre-Matthean tradition creatively, imaginatively, and fictionally, expanded the birth-story of Moses. In gospel, Matthew creatively, imaginatively, and fictionally, expanded the birth-story of Jesus, on the model of that former expansion. Maybe gospel should not be called midrash but those parallel expansions should be called what they are: biblical fictions, parabolic inventions for theological purposes. 
way, why Matthew must tell the infancy story from the viewpoint of Joseph and not of Mary. He is watching consistently the Mosaic parallelism with its emphasis on the father Amram and not on the mother Jochebed. Here is the distribution of his narrative over that sequence from the table above:

- $\quad$ Dream (2:1-2,12): In the time of King Herod, after Jesus was born in Bethlehem of Judea, wise men from the East came to Jerusalem, asking, "Where is the child who has been born king of the Jews? For we observed his star at its rising, and have come to pay him homage" .... And having been warned in a dream not to return to Herod, they [the Magi] left for their own country by another road.

- $\quad$ Fear (2:3): When King Herod heard this, he was frightened, and all Jerusalem with him;

- Message (2:4-5): and calling together all the chief priests and scribes of the people, he inquired of them where the Messiah was to be born. They told him, "In Bethlehem of Judea ...."

- $\quad$ Plot (2:16): When Herod saw that he had been tricked by the wise men, he was infuriated, and he sent and killed all the children in and around Bethlehem who were two years old or under, according to the time that he had learned from the wise men.

- $\quad$ Divorce (1:18-19): When his mother Mary had been engaged to Joseph, but before they lived together, she was found to be with child from the Holy Spirit. Her husband Joseph, being a righteous man and unwilling to expose her to public disgrace, planned to dismiss her quietly.

- $\quad$ Prophecy (1:20-21): But just when he had resolved to do this, an angel of the Lord appeared to him in a dream and said, "Joseph, son of David, do not be afraid to take Mary as your wife, for the child conceived in her is from the Holy Spirit. She will bear a son, and you are to name him Jesus, for he will save his people from their sins." 
- $\quad$ Remarriage (1:24-25): When Joseph awoke from sleep, he did as the angel of the Lord commanded him; he took her as his wife,

- $\quad$ Birth (1:25; 2:1): but had no marital relations with her until she had borne a son; and he named him Jesus.

It is obvious, of course, that Matthew includes in that structure other traditional and redactional materials of his own and those additions involve two major structural changes.

First, there is Matthew's new Balaam-modeled creation of the Magi which effects three changes. The King's Decree starts with Pharaoh's dream in the Moses tradition. But Matthew could never have started with Herod's dream in his parallel narrative. The five dreams he uses in 1:20; 2:12,13,19,22 are all salvific ones from God to good people and not harmful suggestions to evil ones. The addition of the Magi allows him to start The Kings's Decree not with Herod's dream but with their advent. And, thereafter, that dream can be relocated from Herod to them (the other dreams are all for Joseph). Thus, Matthew's dreams remain positive divine commands without intruding a negative royal nightmare among them.

Second, there is a reversal in the story's structure from Moses to Jesus. In the Mosaic stories The King's Decree had to precede The Father's Decision since decree caused decision. Matthew has the opposite sequence. He could have gone either way but, had he kept to the Mosaic one, it would have entailed either a flash-back about an already-born Jesus or else keeping the Magi waiting while Jesus was born. It was simplest to sequence The Father's Decision followed by The King's Decree.

Finally, there is the pre-Matthean virginal conception which has, of course, no parallel whatsoever in the Mosaic tradition. Matthew had to combine that theme with the Abstention/Intercourse, Non-Marriage/Marriage, or Divorce/Remarriage from the Moses tradition. He needed to create some paternal hesitation be it of doubt and perplexity or separation and divorce. Also, there must be a revelatory dream to resolve that problem. There must also be a 
declaration to the parents that the destined child is "theirs." Read, once again, what Joseph did in that earlier citation of Matthew 1:18-25. His private conviction of adultery (others would presume a too-early marriage consummation) sets up the problem. The dream reassures him both about Mary and about her son who "will save his people from their sins" as Moses would "deliver the Hebrew race from their bondage in Egypt." But, in the very process of that fusion, he himself raised the question of adultery which would haunt his story from antiquity to modernity. Matthew's creative composition begot, I suggest, a very obvious rebuttal, an immediate counter-story from opponents. Imagine the normal namecalling of infighting between factions of the same religion. Pro-Jesus Jews: he was born of God by a virgin mother without any human father. Anti-Jesus Jews: if Joseph is not his father, Mary is an adulteress, and Jesus is a bastard. You say virginal conception by divine power. We say adulterous conception and not just by a sinful fellow-Jew but by a pagan, Roman soldier. And, to be fair, Matthew's need for his Jesus/Moses and Amram/Joseph parallel almost invited that response.

\section{JESUS AND CAESAR}

There is one final point. The virginal conception of Jesus is recorded in both Matthew 1-2 and Luke 1-2 and was not therefore first proposed by either of them (even if nobody else in the New Testament knows that tradition). But the conjunction with Isaiah 7:14 is only made explicitly in Matthew 1:23, in Luke 1:31 it is, at very best, implicit. ${ }^{30}$ In other words, we cannot presume that the conjunction of virginity and prophecy was part of their common tradition. Nor can we presume, therefore, that prophecy historicized generated virginity proclaimed. Why, then, did that pre-Matthean and pre-Lukan common source announce Mary's virginal conception at all? If you respond that it only recorded what had happened, I would ask why nobody else in the New Testament shows any knowledge of that happening. Note, before proceeding, that virginal conception

30 Although this is debated, the negative option is followed by Raymond E Brown (1993:153, 524); and by Joseph A Fitzmyer (1981-85:336). 
presumes divine intervention but that divine intervention does not necessarily presume virginal conception. With Mary, then, two phenomena are involved, both divine and virginal conception. And both those elements, direct divine intervention and virginal conception are very unusual in Jewish tradition.

Virginity is strikingly unusual against the general biblical tradition of extraordinary conceptions where a child is specially marked for future greatness by being born to aged and/or infertile parents. The classical examples are Isaac in Gen 17:15-21 \& 21:1-3 (old age), Jacob in Gen 25:21 (infertility), Reuben in Gen 29:31-32 (lack of love), Joseph in Gen 30:1-3,22-24 (infertility), Samson in Judg 13:2-25 (infertility), Samuel in 1 Sam 1:1-20 (infertility). In those cases, it is God who opens and shuts the womb for miraculous conception but there is no suggestion of virginal conception.

You can see clearly from the parallelism of John and Jesus in Luke 1-2, that the virginal conception of Jesus is intended to exalt it over the miraculous conception of John and thereby over the entire biblical tradition summarized in the Baptist's aged and infertile parents. ${ }^{31}$ Elizabeth and Zachary "had no child, because Elizabeth was barren, and both were advanced in years" (1:7). On the one hand, from the aspect of miracle (not to speak of the ancient understanding of conception), it might be hard to prove that divine intervention with a virginal mother is more astounding than divine intervention with two aged non-virginal parents. On the other, a child born of an aged and/or infertile mother is visibly known, empirically evident, legally provable, and socially undeniable while one born of a virginal mother can be believed only at that mother's positive statement and the father's negative one. All in all (and pace Luke), the older non-Christian Jewish tradition of indicating a child conceived under divine destiny seems much stronger rather than much weaker than this later Christian Jewish and originally very marginal tradition. So, once again, why did anyone coming from that wiser Jewish tradition ever risk the claim of virginal conception, ever risk the almost

\footnotetext{
${ }^{31}$ Compare, for John and Jesus respectively, the angelic announcements in 1:5-25 and 1:26-38, the publicized births in 1:57-58 and 2:7-14, the circumcision and naming in 1:59-63 and 2:21, the public presentation and prophecy of destiny in 1:65-79 and 2:21-38, and the description of the child's growth in 1:80 and 2:40-52.
} 
inevitable rebuttal of bastardy? (You say Joseph was not Jesus' father? Round here that makes him a bastard!).

One possible response is that individuals, groups, or communities that prized celibacy first retrojected that preference onto the marriage of Joseph and Mary for the conception of Jesus. That is certainly possible and may well explain the virginity-of-Mary emphasis. But it does not explain the direct divine conception. For that, I suggest another explanation.

Sometime after the battle of Actium and apparently from Egypt, the following story began to circulate about the conception of the warlord Octavian as he metamorphosed into the emperor Augustus. ${ }^{32}$

\begin{abstract}
When Atia had come in the middle of the night to the solemn service of Apollo, she had her litter set down in the temple and fell asleep, while the rest of the matrons also slept. On a sudden a serpent glided up to her and shortly went away. When she awoke, she purified herself, as if after the embraces of her husband, and at once there appeared on her body a mark in colors like a serpent, and she could never get rid of it; so that presently she ceased ever to go to the public baths. In the tenth month after that Augustus was born and was therefore regarded as the son of Apollo. Atia too, before she gave him birth, dreamed that her vitals were borne up to the stars and spread over the whole extent of land and sea, while Octavius dreamed that the sun rose from Atia's womb.
\end{abstract}

First, and for what it's worth, conception involves dreams once again. Second, Atia's was not, of course, a virginal conception since Octavian had an older sister

32 The event is told by both Suetonius (c 70-150) and Dio Cassius (c 155-230). The former author tells it only as he comes to the end of Augustus' life and states that, "I have read the following story in the books of Asclepias of Mendes entitled Theologumena." The latter author tells it at the start and without any attribution: "For Caesar, being childless and basing great hopes upon him [Octavian], loved and cherished him, intending to leave him as successor to his name, authority, and sovereignty He was influenced largely by Attia's emphatic declaration that the youth had been engendered by Apollo; for while sleeping once in his temple, she said, she thought she had intercourse with a serpent, and it was this that caused her at the end of the allotted time to bear a son. Before he came to the light of day she saw in a dream her entrails lifted to the heavens and spreading out over all the earth; and the same night Octavius though that the sun rose from her womb." For sources, see John C Rolfe (1979.1:264-267), Suetonius, The deified Augustus 1.94.4; Earnest Cary (1905-06.4:406-409), Dio's Roman History 4.45.1-2. For commentary, see Robin S Lorsch (1997:790-799). 
Octavia. Third, in Luke, by the way, the Jewish God asks Mary's permission. Fourth, that conception made Augustus a "son of god" not only through adoption by the deified Julius Caesar but also, and earlier, by conception from the divine Apollo.

I propose, in other words, that Jesus' divinely virginal conception found in that common source used independently by both Matthew and Luke but by nobody else in the New Testament was not a case of syncretism or copying but of confrontation and opposition. It did not, emphatically did not, take Jesus out of his Jewish tradition but, while holding him firmly there, it placed that Judaism within the Roman Empire and among those Jews who opposed Rome's ideological ascendancy and theological eschatology. Divinity and virginity were dangerous claims for Jesus' conception but they were also one way to oppose and transcend imperial claims for divinity and non-virginity.

\section{Works consulted}

Bloch, R [1954] 1955a. Quelques aspects de la figure de Moïse dans la tradition rabbinique. Cahiers Sioniens 8, 210-285. Reprinted: in Cazelles, H (ed) 1955a, Moïse, l'homme de l'Alliance, 93-167. Tournai: Desclée. (Special edition of Cahiers Sioniens, nos 2-4 of 1954.)

Bloch, $R$ [1955b] 1978. Note methodolique pour l'étude de la literature rabbibnique. Recherchesde Science Religieuse 43, 194-227. Reprinted: Methodological note for the study of Rabbinic literature, in Green, W S (ed) 1978, Approaches to Ancient Judaism, 1:Theory and practice, 51-75, translated by W S Green \& W J Sullivan. Missoula, MT: Scholars Press for Brown University. (Brown Judaic Studies 1.)

Brown, C H 1992. No longer be silent: First century Jewish portraits of Biblical women. Studies in Pseudo-Philo's Biblical Antiquities and Josephus' Jewish Antiquities. Louisville, KY: Westminster/John Knox.

Brown, R E 1993. The birth of the Messiah: A commentary on the infancy narratives in the gospels of Matthew and Luke. New updated edition. New York, NY: Doubleday. (The Anchor Bible Reference Library.)

Cary, E 1905-06. Dio's Roman History 45.1-2. Cambridge, MA: Harvard University Press. (9 vols LCL.)

Cary, E 1905-06. Dio's Roman History 45.1-2. Cambridge, MA: Harvard University Press. (9 vols LCL.) 
Chilton, B 2000. Rabbi Jesus: An intimate biography. New York, NY: Doubleday. Crossan, J D 1968. Structure and theology of Matthew 1.18-2.23. Cahiers de Joséphologie 16, 119-135,

Crossan, J D 1986. From Moses to Jesus: Parallel themes. Bible Review 2(2), 18-27. Crossan, J D 1998. The birth of Christianity. San Francisco, CA: HarperSanFrancisco. Eleazar ben Asher ha-Levi [1899] 1971. The chronicles of Jerahmeel or, The Hebrew Bible Historiale: Being a collection of apocryphal and pseudo-epigraphical books dealing with the history of the world from the creation to the death of Judas Maccabeus. Translated for the first time from an unique manuscript in the Bodleian Library. Oriental Translation Fund, ns 4. London: Oriental Translation Fund Publications. Reprint, with "Prolegomenon" by Haim Schwarzbaum. New York, NY: Ktav, 1971.

Feldman, L G 1989. Josephus' Jewish Antiquities and Pseudo-Philo's Biblical Antiquities, in Feldman, L H \& Hata, G (eds), Josephus, the Bible, and History, 58-80.

Detroit, MI: Wayne State University Press.

Fitzmyer, J A 1981-85. The Gospel according to Luke. 2 vols with continuous pagination. Garden City, NJ: Doubleday. (AB 28-28a.)

Ginzberg, L 1956. Legends of the Bible. New York, NY: Simon \& Schuster. Harrington, D J 1970. The original language of Pseudo-Philo's Liber Antiquitatum Biblicarum. Harvard Theological Review 63, 503-514.

Harrington, D J 1971. The Biblical text of Pseudo-Philo's Liber Antiquitatum Biblicarum. Catholic Biblical Quarterly 33, 1-17.

Harrington, D J 1974. The Hebrew fragments of Pseudo-Philo's Liber Antiquitatum Biblicarum Preserved in the Chronicles of Jerahmeel. Texts and Translations 3, Pseudepigrapha Series 3. Cambridge, MA: Harvard University Press.

Harrington, D J 1985. Pseudo-Philo: A new translation and introduction, in Charlesworth, J H (ed), The Old Testament Pseudepigrapha, vol 2, 297-377. Garden City, NY: Doubleday.

Harrington, D J 1989. Birth narratives in Pseudo-Philo's Biblical Antiquities and the Gospels, in Horgan, M P \& Kobelski, P J (eds), To touch the text: Biblical and related studies in honor of $\mathrm{J}$ A Fitzmyer, 316-324. New York, NY: Crossroad.

Harrington, D J, Cazeaux, J, Perrot, C \& Bogaert, P-M 1976. Pseudo-Philon, Les Antiquités Bibliques. 2 vols Sources Chrétiennes 229-230. Paris: Cerf.

Hoffman, R J 1987. Celsus: On the True Doctrine. New York, NY: Oxford University Press.

James, M R [1917] 1971. The Biblical Antiquities of Philo. Translations of early documents, 1: Palestinian Jewish texts. London: SPCK. Reprinted with "Prolegomenon" [pp IX-LXIX] by Feldman. L H 1971, The library of Biblical studies. New York, NY: Ktav. 
Johnson, L T 1989. The New Testament's anti-Jewish slander and the conventions of ancient polemic. JBL 108, 419-441.

Johnson, L T 1996. The real Jesus: The misguided quest for the historical Jesus and the truth of the traditional Gospels. San Francisco, CA: HarperSanFrancisco.

Kisch, G 1949. Pseudo-Philo's Liber Antiquitatum Biblicarum. Notre Dame: University of Notre Dame. (Publications in Mediaeval Studies 10.)

Lorsch, R S 1997. Augustus' conception and the heroic tradition. Latomus 56, 790-799.

Maher, M 1994. Targum Pseudo-Jonathan: Exodus, in Targums Neofiti I and PseudoJonathan, 159-289, 310-326. The Aramaic Bible, Vol 2. Collegeville, MN: Liturgical Press (Michael Glazier).

Rolfe, J C 1979. Suetonius. Cambridge, MA: Harvard University Press. (2 vols LCL.)

Sanders. E P 1985. Jesus and Judaism. Philadelphia, PA: Fortress Press.

Sanders, E P 1993. The historical fgure of Jesus. London, UK: Allen Lane/The Penguin Press.

Schaberg, J [1987] 1990. The illegitimacy of Jesus: A feminist theological interpretation of the infancy narratives. San Francisco, CA: Harper \& Row, 1987/New York, NY: Crossroad, 1990.

Thackeray, H St et al 1926-65. Josephus. Cambridge: Harvard University Press. (10 vols LCL.) 